\title{
Compost Extract as a Nutrient Source for Algal Cultures
}

\section{Flávia Martins Franco de Oliveira ${ }^{1 *}$ and Maria Cristina Basílio Crispim²}

${ }^{1}$ PRODEMA, Laboratório de Ecologia Aquática, DSE, Universidade Federal da Paraíba, João Pessoa, Paraíba, Brazil

${ }^{2}$ Laboratório de Ecologia Aquática, DSE, Universidade Federal da Paraíba, João Pessoa, Paraíba, Brazil

\begin{abstract}
Aquaculture is an efficient protein production activity that needs to be encouraged in order to reduce fishing pressure towards native fishes. The use of organic compost extract for algal cultures comes about as an ecological alternative reusing solid organic residuals. The present study tested the influence of culture mediums on the growth and development of the microalgaes Dunaliella marina and Nitzschia closterium on laboratory. Two culture treatments were tested: marine water with Conway medium, marine water with a compost extract medium and only marine water (tested as a without enrichment treatment). Higher densities of $D$. marina were observed on the Conway medium, but densities above $1.5 \times 10^{6}$ cells. $\mathrm{mL}^{-1}$ were frequently observed on the compost extract medium. $N$. closterium showed an initial stage of adaptation on both culture mediums and a higher initial density on the compost extract medium. The compost extract medium is an important source of nutrients that can be further used to cultivate algal masses for aquaculture and other uses, therefore providing framework for the reuse of domestic wastewater residuals and, thus, contributing to environmental conservation.
\end{abstract}

Keywords: Aquaculture; Organic compost; Microalgae; Algal culture

\section{Introduction}

Microalgae are amongst the most important primary producers on aquatic environments, comprising the most significant organisms of the food web base. These organisms have long been employed on aquaculture activities. Currently, algae are cultivated for several other purposes including sewage treatment, organic residual management, production of commercially important chemical compounds, and bioconservation of solar energy [1-3]. Nonetheless, a successful culture of microalgae, zooplankton or larvae is highly dependent upon the proper quantity and quality of nutrients.

On natural environments, phytoplankton is comprised of a great number of algae species with different forms and contrasting life strategies. The form and density of each species are important to determine their water column behaviors [4].

Júnior and Neto [5] showed that microalgae provide vitamins, trace elements, macronutrients (e.g. proteins, lipids and carbohydrates) and pigments (e.g. astaxanthin, zeaxanthin, chlorophyll $a$ and phycocyanin), which are highly important for fishes and shrimps.

Furthermore, algal production is particularly important as a food resource for the larvae of animals in which digestive systems are going through structural and functional changes. These changes, in turn, are related to an endogenous (i.e. yolk) to exogenous diet shift during metamorphosis. Therefore, microalgae are supposedly more efficiently digested than artificial fish food [6].

Some authors state that essential fatty acids of live prey are central during the initial stages of fishes, and that planktonic organisms have specific enzymes which are responsible for the growth and survival of larvae [7].

Aquaculture projects, which use natural food sources, highlight the role of the initial components of the food web, such as producers and primary consumers. For example, several studies showed how variations in nutrient availability, culture mediums and stress conditions influenced composition of microalgae communities.

The present study tested the growth and development of the microalgae Dunaliella marina and Nitzschia closterium when subjected to three treatments: Conway medium, compost extract medium and without enrichment.

\section{Methods}

Experiments of the present study were conducted in laboratory. Three culture treatments were tested: marine water with Conway medium, marine water with compost extract medium and marine water (Without enrichment treatment). The main nutrient ( $\mathrm{N}$ and $\mathrm{P}$ ) were analyzed in all treatments and is presented in Table 1 . The effects of these treatments were tested on two microalgae species: Dunaliella marina and Nitzschia closterium.

The experiment was conducted on the Laboratório de Ecologia Aquática/DSE/CCEN/Universidade Federal da Paraíba (708'19.75”S and $\left.34^{\circ} 50^{\prime} 41.10^{\prime \prime} \mathrm{W}\right)$. Solid residuals were provided by the university's public restaurant. The compost was produced by alternating layers of solid organic residuals and sand. To increase air circulation, the compost was periodically stirred with a PVC stick, and watered to maintain humidity, following the procedures described by Oliveira [8]. At the end of each month, and for each five liters of marine water, $2 \mathrm{~kg}$

\begin{tabular}{|c|c|c|c|c|}
\hline & NITRITE & NITRATE & AMMONIUM & FOSFATE \\
\hline WE & 0,04 & 0,20 & 1,64 & 0,04 \\
\hline C & 0,76 & 15,81 & 0,05 & 1,09 \\
\hline CE & 0,23 & 1,10 & 0,72 & 0,67 \\
\hline
\end{tabular}

Table 1: Chemical analyses in mg. $\mathrm{L}^{-1}$ (nitrite, nitrate, ammonium and phosphate) of sea water under three different media: Conway (C), Compost Extract (CE) and Without Enrichment (WE), in the beginning of the algal growth experiment.

*Corresponding author: Flávia Martins Franco de Oliveira, PRODEMA, Laboratório de Ecologia Aquática, DSE, Universidade Federal da Paraíba, João Pessoa, Paraíba, Brazil; E-mail: fmf_oliveira@hotmail.com

Received May 09, 2013; Accepted September 27, 2013; Published October 08 , 2013

Citation: de Oliveira FMF, Crispim MCB (2013) Compost Extract as a Nutrient Source for Algal Cultures. J Aquac Res Development 4: 195 doi:10.4172/21559546.1000195

Copyright: () 2013 de Oliveira FMF, et al. This is an open-access article distributed under the terms of the Creative Commons Attribution License, which permits unrestricted use, distribution, and reproduction in any medium, provided the original author and source are credited. 
of compost extract were removed and reserved for a period of two days. Subsequently, the water was filtered using GF/C filter papers, autoclaved and set aside for an additional day for cooling and reoxygenation, when the samples were prepared and the algae introduced. Marine water used on the cultures were also filtered using GF/C filter papers and autoclaved.

Microalgal cultures were kept under controlled conditions in laboratory with temperature ranging from 23 to $25^{\circ} \mathrm{C}$. Furthermore, illumination remained constant during the experiment period using two fluorescent $40 \mathrm{~W}$ lamps ( 24 hours). Aeration was not provided and, for each treatment, three $175 \mathrm{ml}$ replicates were employed. Salinity varied between 30 and 33 during the study period. Counting of individuals was conducted using a Fuchs-Rosenthal counting chamber on an Oympus BX41 binocular microscope with magnifications of 10x (ocular lens) and 40x (objective lens) (Rosenthal Albert Sass).

The equation [9] employed for counting individuals followed:

Number of cells $/ m L=\frac{n 1+n 2}{2} \times 10^{3} \times d$

Where:

n1: number of cells on the upper portion

$\mathrm{n} 2$ : number of cells on the lower portion

$\mathrm{d}$ : dilution factor ( $\mathrm{d}=1$; no dilution was made)

The equation employed to evaluate growth rates followed:

$r=\frac{N t 1-N t 0}{T}$

Where:

r: growth rate

Nt1: number of individuals on the day

Nt0: number of individuals on the former day

T: number of days

Statistical tests conducted for algal density and culture mediums included Kruskal-Wallis, which evaluated the growth rates of $N$. closterium and D. marina amongst the three treatments (Conway medium, compost extract medium and Without enrichment), and Mann Whitney, which compared the growth rates between species at each of the three treatments.

\section{Results}

\section{Dunaliella marina}

The highest development of $D$. marina was observed on the Conway medium, with over $2.6 \times 10^{6}$ cells. $\mathrm{mL}^{-1}$ after the $5^{\text {th }}$ day. Peak density was observed on the $22^{\text {nd }}$ day with $3.5 \times 10^{6}$ cells. $\mathrm{mL}^{-1}$. On the compost extract medium, initial growth rates were higher than the other medium, increasing from an initial density of $0.24 \times 10^{6}$ cells. $\mathrm{mL}^{-1}$ ( $1^{\text {st }}$ day) to $2.0 \times 10^{6}$ cells. $\mathrm{mL}^{-1}\left(5^{\text {th }}\right.$ day). Subsequently, densities remained above $1.5 \times 10^{6}$ cells. $\mathrm{mL}^{-1}$ and below $2.2 \times 10^{6}$ cells. $\mathrm{mL}^{-1}$ throughout the experiment period (Figure 1).

Microalgae development was lower at the Without enrichment treatment (only marine water) compared to the other mediums and showed low fluctuations, with an initial density of $0.24 \times 10^{6}$ cells $/ \mathrm{mL}$ and peak density of $0.57 \times 10^{6}$ cells. $\mathrm{mL}^{-1}\left(5^{\text {th }}\right.$ day).

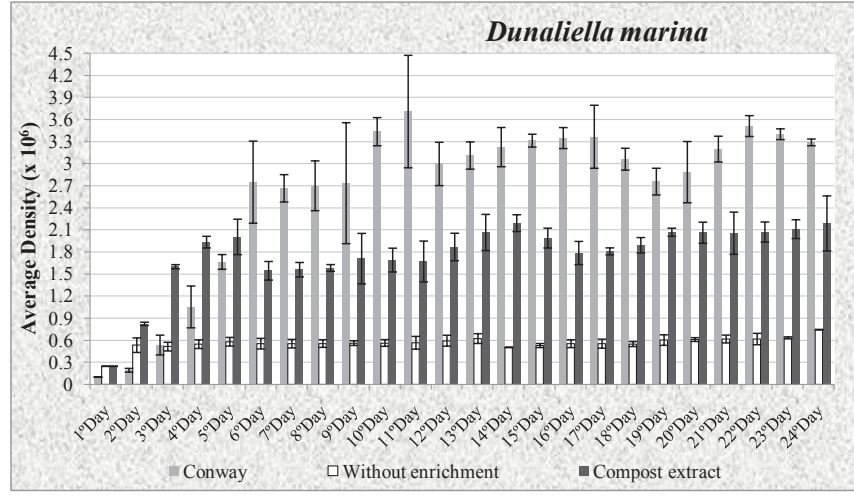

Figure 1: Mean density of $D$. marina cultivated on three culture mediums (Conway, Compost extract and without enrichment) in the laboratory throughout the study period.

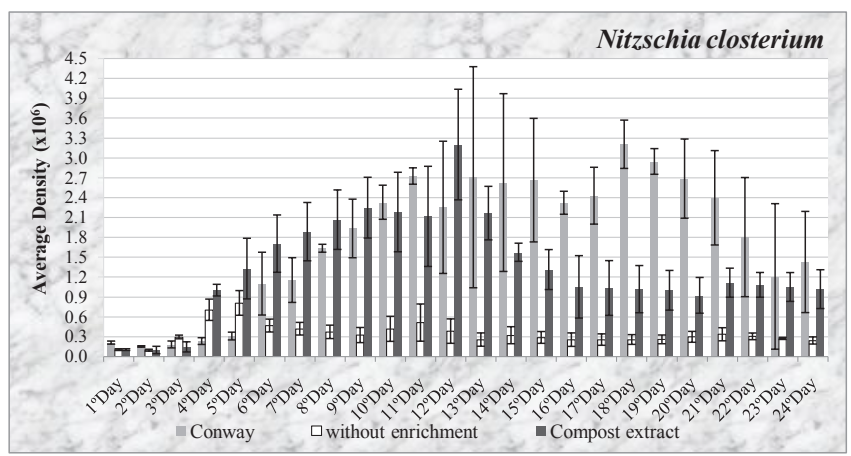

Figure 2: Mean density of $N$. closterium cultivated on three culture mediums (Conway, Compost extract and without enrichment) in the laboratory throughout the study period.

Furthermore, the exponential phase of $D$. marina came about earlier on the compost extract medium (i.e. 5 days) when compared to the Conway medium (i.e. 11 days). Nevertheless, higher densities were observed in the later treatment.

The compost extract medium showed initial higher values of mean growth rates than the other mediums, till the day 5 , afterwards densities were higher in Conway medium, in which peak density was observed during the $11^{\text {th }}$ day.

\section{Nitzschia closterium}

Development of $N$. closterium was somewhat less homogenous than that observed for D. marina at the three treatments. At the compost extract, growth rate started at $0.1 \times 10^{6}$ cells. $\mathrm{mL}^{-1}\left(1^{\text {st }}\right.$ day) peaked at $2.24 \times 10^{6}$ cells. $\mathrm{mL}^{-1}$ ( $9^{\text {th }}$ day), presented oscillations in growth till $13^{\text {th }}$ day and declined thereafter.

Density was higher at Conway medium after the $10^{\text {th }}$ day, with $2.72 \times 10^{6}$ cells. $\mathrm{mL}^{-1}$, and peaked during the $18^{\text {th }}$ day with $3.2 \times 10^{6}$ cells. $\mathrm{mL}^{-1}$ (Figure 2).

On the without enrichment medium, density peaked during the $5^{\text {th }}$ day with $0.8 \times 10^{6}$ cells. $\mathrm{mL}^{-1}$. This peak corresponded to the highest observed value during the study period. Further, density was somewhat homogenous on this medium with the lowest recorded density of $0.17 \times 10^{6}$ cells. $\mathrm{mL}^{-1}\left(16^{\text {th }}\right.$ day $)$.

Based on the data, the compost extract seems appropriate to 
cultivate $N$. closterium, given that the exponential phase (until the $12^{\text {th }}$ day) was similar to that of the Conway medium. Therefore, the use of compost extracts by local human populations to produce algal masses should be encouraged, given its low economic costs and ecological benefits (i.e. reuse of solid organic residuals).

The majority of growth rate values from all treatments and throughout the study period ranged between 0.6 and 1.2, but higher values were observed, particularly, during the first experiment days on the compost extract medium ( $4^{\text {th }}$ day).

With regards to the density of $N$. closterium (cells $/ \mathrm{ml}$ ) at the three culture mediums, significant differences were observed only at the without enrichment treatment. On the other hand, density of D. marina varied significantly at the three treatments, achieving higher densities in Conway medium (Figure 3).

Comparing density between algae species on the Conway medium, significant differences were detected, with higher values observed for $D$. marina. On the without enrichment treatment, significant differences were also observed, with $D$. marina also showing higher density. Similarly, significant differences were also observed at the compost extract medium due to a higher density of D. marina (Figure 4). This suggests that the development of different algae species differed on similar culture mediums.

\section{Discussion}

The use of organic composts serves as an alternative nutritional means to cultivate algae, given that at least three major benefits are associated to its use: low cost, sustainable ecological outcomes and rapid growth rates, similarly to the Conway medium. Sediyama et al. [10], for example, chemically analyzed the quantity and type of nutrients on organic compounds derived from plant debris and pig manure, and

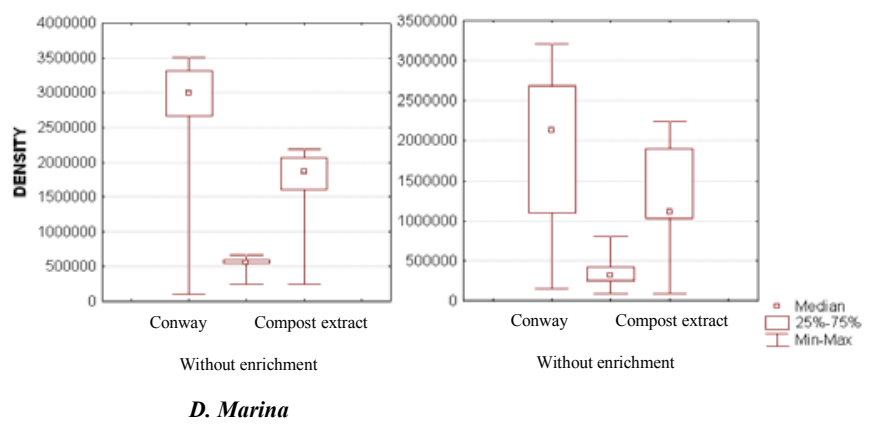

Figure 3: Statistic test on the density (cells $/ \mathrm{ml}$ ) of Dunaliella marina (Left) and Nitzschia closterium (Right) on three culture medium (Conway, Compost extract and without enrichment).

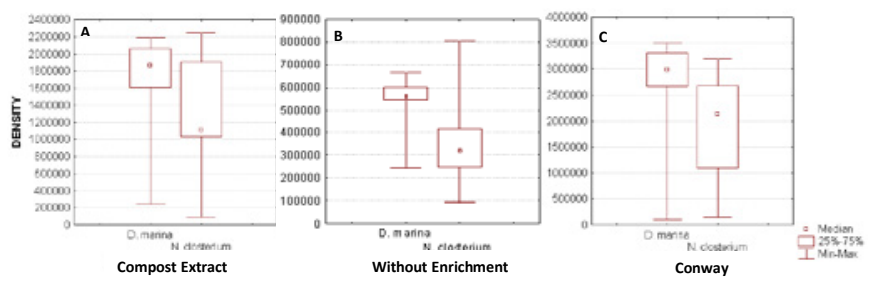

Figure 4: Statistic test on the density (cells $/ \mathrm{ml}$ ) of Dunaliella marina and Nitzschia closterium on the Compost extract medium (A) on the without enrichment medium (B) and on the Conway medium (C). found at least 15 types of nutrients with contrasting concentrations ( $C$, $\mathrm{N}, \mathrm{P}, \mathrm{K}, \mathrm{Ca}, \mathrm{Mg}, \mathrm{S}, \mathrm{Fe}, \mathrm{Zn}, \mathrm{Mn}, \mathrm{Cu}, \mathrm{Al}, \mathrm{Si}, \mathrm{B}, \mathrm{Mo}$ ). On the other hand, Veras \& Povinelli [11] recorded higher quantities of six nutrients (C, $\mathrm{N}, \mathrm{P}, \mathrm{K}, \mathrm{Ca}, \mathrm{Mg}$ ) on organic compounds derived from urban wastes, compared to sediments collected from lakes affected by industrial waste.

Both compost extract and Conway mediums showed somewhat high algal densities and statistic tests revealed significant differences between these mediums and the control treatment. Yet significant differences between the compost extract and the Conway mediums were not detected, showing that compost extract is so appropriate as a culture medium as another scientifically tested and approved. On the other hand, density of $N$. closterium showed high fluctuations and a brief stationary phase. However, values above $2.2 \times 10^{6}$ cells. $\mathrm{mL}^{-1}$ were recorded on the compost extract medium, supporting the results of Griffith et al. as cited by Oliveira and Koening [12], which stated that it is possible to achieve values above $1.0 \times 10^{6}$ cells. $\mathrm{mL}^{-1}$ by means of an artificial medium.

The Conway medium seems more efficient on the long-term, probably it is more complete and has known quantities of nutrients. This is also the case for the Erd Schreiber medium evaluated by Sebastien and Klein [13], which tested the effects of this medium on the cultivation of the microalgaes Dunaliella salina, Tetraselmis chuii and Isochrysis galbana. Moura-Júnior [14], evaluating the growth rates of Chaetoceros gracilis and Tetraselmis gracilis on Guillard's $\mathrm{f} / 2$ medium during eight days, found that the latter species achieved higher densities, (above $4 \times 10^{8}$ cells. $\left.\mathrm{L}^{-1}\right)$ than the former species $\left(5 \times 10^{7}\right.$ cells. $\left.\mathrm{L}^{-1}\right)$. This shows that each species has different nutrient needs.

The compost extract medium also seems to be highly efficient, particularly for D. marina, which showed high densities and higher stability during the stationary phase, supporting the results of Oliveira [8]. Klein and Gonzales [15], testing the effectiveness of several mediums (i.e. fish broth, stillage waste, slaughterhouse wastewater and ERD Schreiber), found that optimal cell density was observed on the first medium (i.e. fish broth), which achieved $2.0 \times 10^{6}$ cells. $\mathrm{mL}^{-1}$.

Analyzing the growth efficiency of the microalgae Tetraselmis chuii and Dunaliella viridis using urban secondary sewage under five types of treatments, Costa et al. [16], observed that both species reached higher densities in treatments with the highest percentage of urban sewage. Organic fertilizers based on fish broth and cattle manure were tested in exponential growth for Tetraselmis chuii, obtaining positive results with densities of $0.45 \times 10^{6}$ cells. $\mathrm{mL}^{-1}[12]$.

In this work, the densities obtained for both algae grown in compost, were far superior to the work of Oliveira \& Koening (opus cit.), surpassing $2.0 \times 10^{6}$ cell. $\mathrm{mL}^{-1}$ (D. marina) and $3.0 \times 10^{6}$ cells. $\mathrm{mL}^{-1}(\mathrm{~N}$. closterium). These densities are similar to those registered by Abu-Rezq et al. [17], testing different phosphate concentrations in other species of Dunaliella, D. salina and by Sathasivam and Juntawong [18] using modified Jonhson's medium.

Kim et al. [19], using also an organic medium based with a treated swine urine solution, testing three species of Scenedesmus noticed that the species grew several times more in the presence of the swine urine than in the presence of Bold's Basal medium (BBM).

Densities in the magnitude of 104 are sufficient to promote growth of some cladocerans. Therefore, the compost extract medium, that achieved densities up to 2.1 (D. marina) and 3.0 (N. closterium) serves as a sustainable alternative to produce phytoplankton for aquaculture. 
According to Fábegas et al. [20], associated to appropriate aeration, this medium may double or triple algal biomass. This author recorded an increase in the growth rate and cell productivity by increasing aeration: Dunaliella tertiolecta showed a density of $7.0 \times 10^{6}$ cells. $\mathrm{mL}^{-1}$ without aeration, which increased to $12.4 \times 10^{6}$ cells. $\mathrm{mL}^{-1}$ following an aeration of 6.51 L. $\mathrm{min}^{-1}$.

As larviculture is a needed process in the majority of the aquaculture processes, and the development of less expensive and more ecological ways is required. The use of organic compounds to produce microalgae culture medium avoids the launch of this kind of residuals in the environment, decreasing water pollution.

\section{Conclusions}

- Evaluations of different culture mediums revealed that the Conway medium was most effective to cultivate the microalgae D. marina. However the compost extract medium also proved to be effective to cultivate this species, achieving positive results on both stability and exponential growth.

- For both studied algae, peaks of exponential growth were achieved more rapidly at the compost extract medium.

- On all culture mediums, density of the two algae species $(D$. marina and $N$. closterium) differed significantly, suggesting that each medium plays different effects on their development. For example, the Conway medium was more effective for $D$. marina.

- On each culture medium, differences between species were also observed. Therefore, the effects of culture mediums are speciesspecific and growth rates between species differed on similar mediums.

- The organic compost extract medium is an important source of nutrients and can be successfully employed to cultivate algal masses.

- The use of solid organic residuals to produce composts for algal cultivation serves as an ecological alternative to reuse these residuals with positive and environmentally friendly outcomes.

\section{Acknowledgment}

We thank CNPq for the support to Flávia Martins Franco de Oliveira with a master degree scholarship.

\section{References}

1. Goldman JC (1979) Outdoor algal mass cultures- I. Applications. Water Res 13: $1-19$

2. Nieves M, Voltolina D, Ruiz JL, Cisneros MA, Piña P (2000) Cultivo de Microalgas marinas com médios enriquecidos com Productos de Naturaleza Zeolítica. Hidrobiológica 10: 1-6.

3. Betz JA (2009) Biodiesel de Algas: Passado, Presente e Futuro nos Estados Unidos da América e na Flórida. Monografia. Escola politécnica da Universidade Federal do Rio de Janeiro. 47p.

4. Giani A, Leonardo IM (1988) Distribuição Vertical de Algas Fitoplanctônicas no Reservatório da Pampulha (Belo Horizonte). Acta Limnologica Brasiliensia 2: 1-388.

5. Júnior RCB, Neto AO (2001) Camarões Marinhos: Reprodução, Maturação e Larvicultura. Aprenda Fácil Editora, Viçosa-MG, 255p.
6. Piedras SRN, Pouey JLOF (2004) Alimentação de Alevinos de Peixe-Re (Odontesthes Bonariensis) com Dietas Naturais e Artificiais. Ciênc Rural 34: 1203-1206.

7. Sipaúba-Tavares LH, Rocha O (1993) Cultivo em larga escala de organismos planctônicos para alimentação de larvas e alevinos de peixes: I. Algas clorofíceas. Biotemas 6: 93-106.

8. Oliveira FMF (2006) Efeito da quantidade e qualidade de alimento sobre algumas espécies de cladocera (Crustácea Branchiopoda). MonografiaUniversidade federal da Paraíba, João Pessoa - PB.

9. FAO (2008) Fórmula da Câmara de contagem, acessado em Novembro de 2008, Disponível em.

10. Sediyama MAN, Garcia NCP, Vidigal SM, Matos AT (2000) Nutrientes em compostos orgânicos de resíduos vegetais e dejetos de suínos. Sci Agri 57.

11. Veras LRV, Povinelli J (2004) A vermicompostagem do lodo de lagoas de tratamento de efluentes industriais consorciada com composto de lixo urbano. Eng Sanit Ambient 9: 218-224.

12. Oliveira AAG, Koening ML (1984) Crescimento exponencial de Tetraselmis chuii com fertilizantes orgânicos. Arq. Biol. Tecnol 27.

13. Sebastien NY, Klein VLM (2006) Efeito do meio Erd Schreiber no cultivo das microalgas Dunaliella salina, Tetraselmis chuii e Isochrysis galbana. Acta Scientiarum Biological Sciences 28: 149-152.

14. Moura-Júnior AM, Bezerra NE, Koening ML, Leça EE (2007) Chemica Composition of Three Microalgae Species for Possible Use in Mariculture. Braz Arch Biol Techn 50: 461-467.

15. Klein VLM, Gonzalez AAW (1993) Cultivo da microalga Tetraselmis chuii Prings em diferentes meios de cultura. Ciênc. Agron. Fortaleza 24: 91-100.

16. Costa RAAM, Koening ML, Macedo SJ (2004) Urban secondary sewage: an alternative médium for the culture of Tetraselmis chuii (prasinophyceae) and Dunaliella viridis (chlorophyceae). Braz Arch Biol Techn 47.

17. Abu-Rezq TS, Al-Hoot S, Jacob DA (2010) Optimum culture conditions required for the locally isolated Dunaliella salina. J Algal Biomass Utln 1: 12-19.

18. Sathasivam R, Juntawong N (2013) Modified medium for enhanced growth of Dunaliella strains, Int J Curr Sci 5: 67-73.

19. Kim MK, Park JW, Park CS, Kim SJ, Jeune KH, et al. (2007) Enhanced production of Scenedesmus spp. (green microalgae) using a new medium containing fermented swine wastewater. Bioresour Technol 98: 2220-2228.

20. Fábregas J, Férron L, Gamalho Y, Vecino E, Otero A, et al. (1994) Improvement of growth rate and cell productivity by aeration rate in cultures of the marine microalga Dunaliella tertiolecta. Bioresoure Technol 48: 107-111. 